\title{
Miskonsepsi Pembebanan Tanggung Jawab kepada Direksi Badan Usaha Milik Negara dalam Jerat Tindak Pidana Korupsi
}

\author{
Bayu Novendra ${ }^{1}$, Aulia Mutiara Syifa ${ }^{2 *}$ \\ ${ }^{1,2}$ Fakultas Hukum Universitas Indonesia, Depok, Indonesia \\ E-mail: aulia.mutiara71@ui.ac.id
}

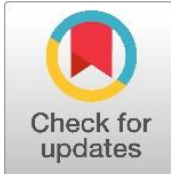

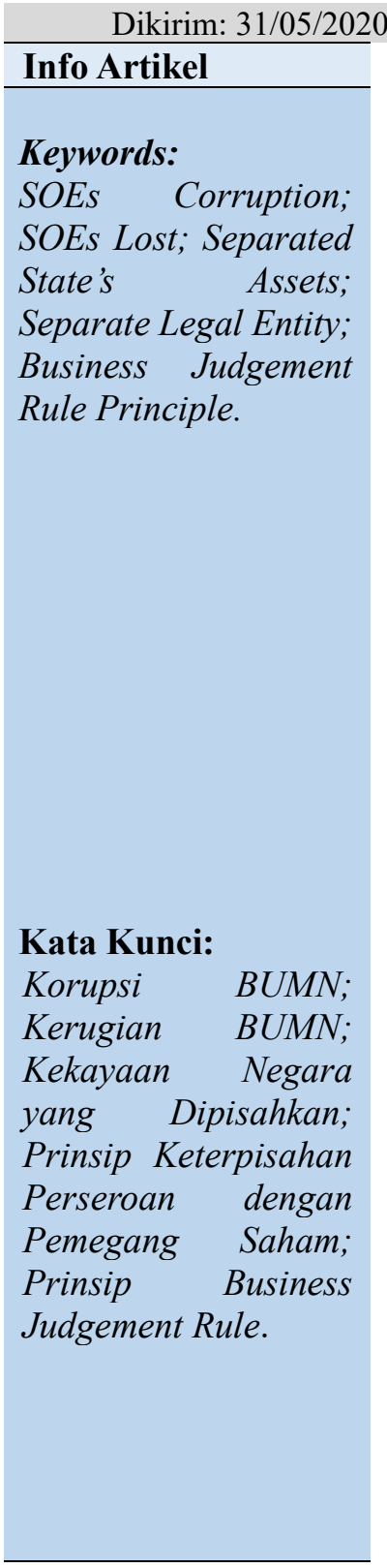

\begin{tabular}{l} 
Direvisi: 01/10/2020 Dipublikasi: 25/12/2020 \\
\hline Abstract \\
The dualism of the conception of state assets separated in State-Owned \\
Enterprises (SOEs) in Indonesian legislation raises a polemic in the \\
operation of SOEs as a business entity. In essence, in Act Number 19 of \\
2003 concerning SOEs, separated state assets no longer include state \\
assets and their development and management are based on sound \\
corporate principles. Meanwhile, in Law Number 17 of 2003 concerning \\
State Finance, it is stated that one of the state finances is state assets \\
separated from SOEs. Therefore, if it is related to the enactment of Law \\
Number 31 of 1999 concerning Eradication of Corruption, SOEs that \\
suffer losses can be charged with criminal acts of corruption because \\
they have harmed state finances. By using the juridical-normative \\
method and literature study as data collection techniques, the results of \\
this study confirm the nature of BUMN as a company that is separate \\
from its shareholder, namely the state. This research also encourages the \\
use of Business Judgment Rule principle in proof as an effort to protect \\
all actions of the Directors of BUMN that have a good intention to run \\
a BUMN that suffers losses.
\end{tabular}

\section{Abstrak}

Dualisme konsepsi kekayaan negara yang dipisahkan di Badan Usaha Milik Negara (BUMN) dalam peraturan perundang-undangan Indonesia menimbulkan polemik dalam penyelenggaraan usaha BUMN sebagai suatu badan usaha. Hakikatnya, kekayaan negara yang dipisahkan sebagai penyertaan modal BUMN bukan termasuk keuangan negara dan pembinaan serta pengelolaannya didasarkan pada prinsip good corporate governance. Namun, dalam Undang-Undang Keuangan Negara, yang termasuk keuangan negara salah satunya adalah kekayaan negara yang dipisahkan pada BUMN. Sehingga, Direksi BUMN yang mengalami kerugian dapat dijerat tindak pidana korupsi karena telah merugikan keuangan negara. Nyatanya, tidak selalu kerugian BUMN terjadi karena suatu niat jahat untuk menguntungkan diri sendiri, justru lebih banyak terjadi karena dinamika usaha. Dengan menggunakan metode yuridis-normatif dan studi kepustakaan sebagai teknik pengumpulan data, hasil dari penelitian ini menegaskan hakikat BUMN sebagai suatu perseroan yang terpisah dari pemegang sahamnya, yakni 
DOI:

10.47268/sasi.v26i4.298 negara. Penelitian ini juga mendorong penggunaan prinsip Business Judgement Rule dalam pembuktian sebagai upaya perlindungan atas segala tindakan Direksi BUMN yang telah beritikad baik menjalankan BUMN yang mengalami kerugian.

\section{A. PENDAHULUAN}

Perekonomian nasional Indonesia sebagai salah satu cara untuk mencapai tujuan bernegara diatur ketentuannya dalam konstitusi Indonesia, yakni Undang-Undang Dasar 1945, tepatnya di dalam Pasal 33. Badan Usaha Milik Negara ("BUMN") merupakan bagian dari pelaku dalam sistem perekonomian nasional yang disusun sebagai usaha bersama berdasar atas asas kekeluargaan, sebagaimana yang diamanatkan dalam Pasal 33 ayat (1) Undang-Undang Dasar 1945. BUMN memiliki fungsi untuk mengelola usaha yang objeknya adalah cabang-cabang produksi yang penting bagi negara dan yang menguasai hajat hidup orang banyak, ataupun mengelola usaha yang objeknya bersumber dari bumi, air, dan kekayaan alam yang terkandung di dalamnya. Pelaksanaan usaha tersebut dikuasai oleh negara dan dipergunakan untuk sebesar-besar kemakmuran rakyat. ${ }^{1}$ Sehingga, secara konstitusional, esensi eksistensi BUMN di Indonesia adalah untuk memperkuat perekonomian negara dengan pengelolaan sumber daya Indonesia yang digunakan untuk sebesar-besarnya kemakmuran rakyat dengan berpegangan pada demokrasi ekonomi dengan prinsip kebersamaan.

Amanat dalam konstitusi tersebut diejawantahkan dalam Undang-Undang Nomor 19 Tahun 2003 tentang BUMN. Dalam Pasal 2 undang-undang tersebut disebutkan bahwa, BUMN memiliki maksud dan tujuan memberikan sumbangan bagi perkembangan perekonomian nasional pada umumnya dan penerimaan negara pada khususnya; mengejar keuntungan; menyelenggarakan kemanfaatan umum berupa penyediaan barang dan/atau jasa yang bermutu tinggi dan memadai bagi pemenuhan hajat hidup orang banyak; menjadi perintis kegiatan-kegiatan usaha yang belum dapat dilaksanakan oleh sektor swasta dan koperasi; dan turut aktif memberikan bimbingan dan bantuan kepada pengusaha golongan ekonomi lemah, koperasi dan masyarakat. ${ }^{2}$ Kemudian, diatur pula dalam Pasal 1 angka 1 undang-undang yang sama, bahwa BUMN adalah badan usaha yang seluruh atau sebagian besar modalnya dimiliki oleh negara melalui penyertaan secara langsung yang berasal dari kekayaan negara yang dipisahkan, dan atasnya negara memiliki kepemilikan saham atasnya jika BUMN tersebut berbentuk perseroan terbatas.

Berdasarkan uraian tersebut, pada hakikatnya BUMN sama seperti perseroan terbatas pada umumnya yang salah satu cirinya adalah memiliki kekayaan yang terpisah dari pemilik modalnya dan hubungan antara pemilik modal, yakni negara dengan BUMN berdasarkan kepemilikan negara atas saham BUMN sehingga selayaknya pengaturan mengenai pengelolaan, tanggung jawab dan beban risiko BUMN tunduk pada ketentuan hukum perdata, yakni peraturan perundang-undangan mengenai perseroan terbatas. Namun, di berbagai peraturan perundang-undangan Indonesia masih ditemukan inkonsistensi dalam pengaturan konsep kekayaan negara yang dipisahkan pada BUMN. Pada pandangan pertama, bersikukuh menyatakan bahwa kekayaan negara yang dipisahkan ke BUMN akan tetap menjadi milik negara. Sedangkan, pada pandangan kedua, begitu negara memisahkan kekayaannya untuk dijadikan penyertaan modal ke BUMN, maka hubungan kepemilikan negara dengan kekayaan tersebut putus dan kekayaan tersebut berpindah menjadi milik

\footnotetext{
1 Pasal 33 ayat (3) Undang-Undang Dasar Negara Republik Indonesia 1945.

2 Pasal 2 Undang-Undang Nomor 19 Tahun 2003 tentang Badan Usaha Milik Negara.
} 
BUMN. Inkonsistensi ini menimbulkan berbagai polemik, terutama dalam hal pertanggungjawaban Direksi BUMN, karena peraturan perundang-undangannya begitu tumpang tindih.

Kepastian mengenai dualisme konsepsi kekayaan negara yang dipisahkan pada BUMN dalam peraturan perundang-undangan Indonesia menjadi penting ketika dihadapkan dengan pertanggungjawaban direksi BUMN. Penegasan tersebut menjadi penting karena kegiatan usaha termasuk dalam BUMN adalah kegiatan yang penuh dengan kemungkinan baik dan buruk suatu hasil serta tingginya persaingan. Kemudian, karena adanya kemungkinankemungkinan buruk tersebut diperlukan kepastian apakah beban yang dipertanggungkan kepada direksi BUMN adalah juga banyak masuk kedalam lingkungan hukum publik misalkan yang paling dekat adalah korupsi (Dalam hal kekayaan negara dan BUMN disatukan), atau hanya lingkungan hukum privat dan sedikit hukum publik (Dalam hal kekayaan negara dan BUMN dipisahkan).

Di sisi lain, dikarenakan adanya kemungkinan baik dan buruk dari hasil suatu kegiatan usaha, berakibat pada dituntutnya direksi selaku pihak yang memiliki kewenangan dalam menjalankan perseroan untuk dapat mengambil suatu kebijakan secara tepat dan cepat. Dalam setiap kerugian yang timbul dari suatu keputusan direksi, tidak serta merta segalanya dipersalahkan atau dimintakan pertanggungjawaban kepada direksi, perseroan juga dapat menanggung risiko bisnis yang timbul dari pengambilan kebijakan oleh direksi. Jika terjadi kerugian, masih dapat ditoleransi dengan batas-batas tertentu mengingat tidak semua bisnis harus mendapat keuntungan. Hal tersebut yang kemudian disebut sebagai doktrin business judgment rule.

\section{B. METODE PENELITIAN}

Metode yang digunakan dalam penelitian ini adalah metode yuridi normatif, yakni penelitian hukum yang dilakukan dengan cara meneliti bahan pustaka atau data sekunder. ${ }^{3}$ Penelitian ini bersifat deskriptif analitis yang menggambarkan peristiwa yang sedang diteliti, kemudian dianalisa berdasarkan fakta berupa data sekunder yang diperoleh dari bahan hukum primer, sekunder maupun tersier. Jenis data yang digunakan adalah data sekunder, atau data yang diperoleh dari penelitian dan pengolahan orang lain, dalam bentuk buku atau dokumen yang biasanya disediakan di perpustakaan atau milik pribadi, seperti peraturan perundang-undangan, buku, artikel jurnal, makalah, dan putusan berkaitan dengan kekayaan negara yang dipisahkan pada BUMN serta pertanggungjawaban Direksi BUMN.

\section{PEMBAHASAN}

\section{Dualisme Konsepsi Kekayaan Negara yang Dipisahkan pada Badan Usaha Milik Negara dalam Peraturan Perundang-Undangan Indonesia}

Hukum Indonesia dalam menjelaskan konsepsi mengenai kekayaan negara yang dipisahkan dalam suatu Badan Usaha Milik Negara terdapat perbedaan. Penyusun membagi perbedaan ini dalam dua rezim. Rezim pertama terdiri atas Undang-Undang tentang Keuangan Negara, Undang-Undang tentang Perbendaharaan Negara serta Undang-Undang tentang Pemberantasan Tindak Pidana Korupsi. Sedangkan rezim kedua adalah UndangUndang tentang Badan Usaha Milik Negara, Undang-Undang tentang Perseroan Terbatas, Undang-Undang tentang Pasar Modal.

\footnotetext{
3 Soerjono Soekanto, Sri Mamudji. (2018). Penelitian Hukum Normatif: Suatu Tinjauan Singkat. Depok: RajaGrafindo Persada, h. 13.
} 
Undang-Undang Nomor 17 Tahun 2003 tentang Keuangan Negara mendefinisikan bahwa keuangan negara adalah semua hak dan kewajiban negara yang dapat dinilai dengan uang, serta segala sesuatu baik berupa uang maupun barang yang dapat dijadikan milik negara berhubung dengan pelaksanaan hak dan kewajiban tersebut. ${ }^{4}$ Undang-undang tersebut juga mengatur mengenai ruang lingkup keuangan negara, yang mana termasuk kekayaan negara atau kekayaan daerah yang dikelola sendiri atau oleh pihak lain berupa uang, surat berharga, piutang, barang, serta hak-hak lain yang dapat dinilai dengan uang, termasuk kekayaan yang dipisahkan pada perusahaan negara atau perusahaan daerah, yang dapat disebut sebagai Badan Usaha Milik Negara (BUMN) dan Badan Usaha Milik Daerah (BUMD). ${ }^{5}$

Pembentuk Undang-Undang tentang Keuangan Negara ini memberikan persepsi bahwa pendefinisian keuangan negara berdasarkan sisi obyek ${ }^{6}$, subyek $^{7}, \operatorname{proses}^{8}$ dan tujuan ${ }^{9}$. Luasnya cakupan keuangan negara tersebut menjadikan pengelolaan keuangan negara dikelompokkan dalam pengelolaan fiskal, pengelolaan moneter, pengelolaan kekayaan negara, dan kekayaan negara yang dipisahkan. ${ }^{10}$

Definisi keuangan negara yang juga mencakup kekayaan negara yang dipisahkan dalam BUMN dan juga BUMD pun juga diterapkan dalam Undang-Undang Nomor 1 Tahun 2004 tentang Perbendaharaan Negara. Pembentuk Undang-Undang tentang Perbendaharaan Negara mendefinisikan perbendaharaan negara sebagai pengelolaan dan pertanggungjawaban negara termasuk investasi dan kekayaan yang dipisahkan dalam Anggaran Pendapatan dan Belanja Negara (APBN) dan Anggaran dan Pendapatan Belanja Daerah (APBD). ${ }^{11}$ Pengertian ini pun juga dituangkan dalam Undang-undang Nomor 31 Tahun 1999 tentang Pemberantasan Tindak Pidana Korupsi yang menyatakan bahwa keuangan negara adalah:

Seluruh kekayaan negara dalam bentuk apa pun, yang dipisahkan atau yang tidak dipisahkan, termasuk di dalamnya segala bagian kekayaan negara dan segala hak dan kewajiban yang timbul karena:

a. berada dalam penguasaan, pengurusan, dan pertanggungjawaban pejabat lembaga negara, baik di tingkat pusat maupun di daerah;

b. berada dalam penguasaan, pengurusan, dan pertanggungjawaban badan usaha milik negara/badan usaha milik daerah, yayasan, badan hukum, dan perusahaan yang menyertakan modal negara, atau perusahaan yang menyertakan modal pihak ketiga berdasarkan perjanjian dengan negara. ${ }^{12}$

4 Pasal 1 angka 1 Undang-Undang Nomor 17 Tahun 2003 tentang Keuangan Negara.

5 Pasal 2 huruf g Undang-Undang Nomor 17 Tahun 2003 tentang Keuangan Negara.

6 Sisi obyek yang dimaksud adalah meliputi semua hak dan kewajiban negara yang dapat dinilai dengan uang, termasuk kebijakan dan kegiatan dalam bidang fiskal, moneter dan pengelolaan kekayaan negara yang dipisahkan, serta segala sesuatu baik berupa uang, maupun berupa barang yang dapat dijadikan milik negara berhubung dengan pelaksanaan hak dan kewajiban tersebut.

7 Sisi subyek yang dimaksud adalah meliputi seluruh obyek yang dimiliki negara, dan/atau dikuasai Pemerintah Pusat, Pemerintah Daerah, BUMN/BUMD, dan badan lain yang ada kaitannya dengan keuangan negara.

8 Keuangan negara dalam sisi proses mencakup seluruh rangkaian kegiatan yang berkaitan dengan pengelolaan obyek mulai dari perumusan kebijakan dan pengambilan keputusan sampai dengan pertanggungjawaban.

9 Sisi tujuan meliputi seluruh kebijakan, kegiatan dan hubungan hukum yang berkaitan dengan pemilikan dan/atau penguasaan obyek dalam rangka penyelenggaraan pemerintahan negara.

10 Penjelasan Umum Undang-Undang Nomor 17 Tahun 2003 tentang Keuangan Negara.

11 Pasal 1 angka 1 Undang-Undang Nomor 1 Tahun 2004 tentang Perbendaharaan Negara.

12 Penjelasan Umum Undang-Undang Nomor 31 Tahun 1999 tentang Pemberantasan Tindak Pidana Korupsi.

461 |S A S I Vo1. 26 No.4, Oktober - Desember 2020 
Sehingga, apabila dikaitkan dengan unsur-unsur tindak pidana korupsi sebagaimana tertuang dalam Pasal 2 ayat (1) Undang-Undang Nomor 31 Tahun 1999 yakni setiap orang yang secara melawan hukum melakukan perbuatan memperkaya diri sendiri atau orang lain yang dapat merugikan keuangan negara atau perekonomian negara, maka terhadap Direksi BUMN yang BUMN-nya mengalami kerugian dapat didakwakan dengan tindak pidana korupsi.

Sebagaimana yang diuraikan sebelumnya, rezim pertama tidak membedakan status uang dan kepemilikan kekayaan dalam suatu badan. Apabila dikaitkan dengan konsep kekayaan negara yang dipisahkan ke BUMN, maka penyertaan modal negara ke BUMN akan tetap menjadi kekayaan negara, bukan menjadi modal BUMN sepenuhnya, dengan dimasukkannya kekayaan negara yang dipisahkan ke bagian dari keuangan negara serta perbendaharaan negara, maka Badan Pemeriksa Keuangan sebagai lembaga yang berwenang untuk memeriksa pengelolaan dan tanggung jawab tentang keuangan negara ${ }^{13}$, dapat memeriksa keuangan dalam BUMN.

Hal ini menimbulkan permasalahan karena mengingat sifat usaha BUMN selain untuk memenuhi hajat hidup orang banyak dan menjadi penggerak perekonomian nasional, juga bertujuan untuk meraih keuntungan. Sedangkan, dalam hal untuk meraih keuntungan, suatu korporasi akan terjun dan bergerak terus dalam dunia usaha dan bisnis yang mana memiliki pergerakan yang sangat dinamis sehingga merupakan suatu hal yang cukup potensial untuk mendapat kerugian apabila iklim bisnis tidak mendukung.

Sehingga, terhadap rezim yang pertama, beberapa ahli menyampaikan kritiknya. Arifin P. Soeria Atmadja menyatakan bahwa Undang-Undang tentang Keuangan Negara yang seharusnya mengatur keuangan negara saja, meluas pengaturannya dan ditengarai sebenarnya pembentuk undang-undang tersebut tidak memahami perbedaan prinsipiil antara keuangan negara, keuangan daerah, keuangan BUMN/BUMD dan bahkan keuangan swasta pun ikut diatur di dalam undang-undang tersebut. ${ }^{14}$ Jusuf Indradewa pun juga menyampaikan pendapatnya atas pengertian keuangan negara tersebut. Menurutnya, keuangan negara adalah keuangan yang sepenuhnya menjadi hak atau kekayaan negara sebagai badan hukum. ${ }^{15}$ Sedangkan, BUMN Persero sebagai badan hukum yang mempunyai status kemandirian, memiliki keuangan atau kekayaan sendiri yang terpisah dari kekayaan negara sebagai pemegang saham. Pendapat Jusuf Indradewa tersebut didasarkan pada konsep perseroan terbatas yang merupakan persekutuan modal dengan pemisahan modal antara sekutu dengan perseroan.

Kritik-kritik terhadap rezim pertama inilah melahirkan pandangan rezim kedua mengenai kekayaan negara yang dipisahkan dalam BUMN. Berdasarkan Undang-Undang Nomor 19 Tahun 2003 tentang Badan Usaha Milik Negara, yang dimaksud dengan BUMN adalah badan usaha yang seluruh atau sebagian besar modalnya dimiliki oleh negara melalui penyertaan secara langsung yang berasal dari kekayaan negara yang dipisahkan. ${ }^{16}$ Kekayaan negara yang dipisahkan dalam kekayaan negara yang berasal dari APBN untuk dijadikan penyertaan modal negara pada Persero dan/atau Perum serta perseroan terbatas lainnya. ${ }^{17}$

13 Pasal 23E ayat (1) Undang-Undang Dasar Negara Republik Indonesia Tahun 1945.

14 Arifin P. Soeria Atmadja. (2004). Carut Marut Undang-Undang Nomor 17 Tahun 2003 tentang Keuangan Negara. Makalah lepas, h. 3.

15 Jusuf Indradewa. (2002). Aspek Hukum dan Hakikat Keuangan Negara dalam Kaitannya dengan Pengelolaan Badan Usaha Milik Negara. Makalah yang disampaikan pada Seminar Reposisi Keuangan Negara: Pengelolaan, Pertanggungjawaban, dan Pemeriksaan Badan Usaha Milik Negara, Jakarta, h. 8.

16 Pasal 1 angka 1 Undang-Undang Nomor 19 Tahun 2003 tentang Badan Usaha Milik Negara.

17 Pasal 1 angka 10 Undang- Undang Nomor 19 Tahun 2003 tentang Badan Usaha Milik Negara. 
Kekayaan negara yang dipisahkan kepada BUMN pembinaan dan pengelolaannya tidak didasarkan lagi pada sistem APBN namun langsung pada prinsip-prinsip perusahaan yang sehat. ${ }^{18}$

Konsep BUMN sebagai salah satu bentuk dari perseroan terbatas mengacu pada konsep yang ada dalam Undang-Undang Perseroan Terbatas. Sebagaimana yang diuraikan dalam Undang-Undang Nomor 40 Tahun 2007 tentang Perseroan Terbatas, pengertian perseroan terbatas adalah:

Badan hukum yang merupakan persekutuan modal, didirikan berdasarkan perjanjian, melakukan kegiatan usaha dengan modal dasar yang seluruhnya terbagi dalam saham dan memenuhi persyaratan yang ditetapkan dalam undang-undang ini serta peraturan pelaksanaannya. ${ }^{19}$

Konsep persekutuan modal dalam perseroan terbataslah yang membedakan perseroan terbatas dengan bentuk badan usaha lainnya. Maksud dari konsep ini adalah berkumpulnya modal ialah suatu hal yang utama. Perseroan terbatas lebih berpotensi untuk menghimpun modal sebesar-besarnya dan melalui pasar modal sebagai salah satu sarana perseroan terbatas untuk menghimpun dana publik untuk digunakan sebagai modal dalam bentuk saham untuk perseroan terbatas, ${ }^{20}$ dalam perseroan terbatas, modal dari para penyetor modal setelah diserahkan, akan menjadi modal dari perseroan terbatas sebagai akibat dari kedudukan perseroan terbatas yang merupakan subyek hukum, yakni berupa badan hukum, sehingga dapat mengemban hak dan kewajiban sendiri, tidak ditanggung oleh sekutu-sekutu di dalamnya. ${ }^{21}$

Sesuai Undang-Undang tentang Badan Usaha Milik Negara, BUMN merupakan perusahaan negara yang berbentuk perseroan maupun perusahaan umum sehingga konsep dari BUMN sendiri pun mengikuti konsep dalam perseroan terbatas. Atas dasar hal tersebut, Arifin P. Soeria Atmadja memandang bahwa sesungguhnya makna pemisahan kekayaan negara yang dipisahkan ini dalam konsep bahwa pemerintah menyisihkan kekayaan negara untuk dijadikan modal penyertaan guna dijadikan modal pendirian perseroan atau untuk menambah dan memperkuat struktur permodalan perseroan terbatas dalam meningkatkan kegiatan usahanya. ${ }^{22}$

Berdasarkan uraian tersebut, rezim kedua memandang kekayaan negara yang dipisahkan dalam suatu BUMN akan menjadi modal dasar BUMN selayaknya seperti mekanisme pemasukan modal ke perseroan terbatas. Dalam pandangan ini, negara dengan memberikan kekayaan negara yang dipisahkan sebagai modal dari BUMN, bertindak selayaknya investor atau pemegang saham dalam perseroan terbatas. Dengan masuknya kekayaan negara yang dipisahkan ke BUMN, maka kekayaan negara tersebut akan melebur menjadi modal BUMN dan negara sebagai gantinya akan mendapatkan saham senilai modal yang diberikannya, yakni $51 \%$ saham untuk BUMN dalam bentuk Perseroan ${ }^{23}$ atau $100 \%$ saham untuk BUMN dalam bentuk Perusahaan Umum. ${ }^{24}$ Sehingga, kekayaan negara yang dipisahkan setelah diberikan ke BUMN tidak akan lagi menjadi kekayaan negara. Pandangan

18 Penjelasan Pasal 4 ayat (1) Undang- Undang Nomor 19 Tahun 2003 tentang Badan Usaha Milik Negara.

19 Pasal 1 angka 1 Undang-Undang Nomor 40 Tahun 2007 tentang Perseroan Terbatas.

20 Agus Sardjono, Yetty Komalasari Dewi, Rosewitha Irawaty, Togi Pangaribuan. (2018). Pengantar Hukum Dagang. Depok: Rajagrafindo Persada, h. 73.

21 Ibid., h. 71.

22 Arifin P. Soeria Atmadja. (2007). Transformasi Status Hukum Uang Negara sebagai Teori Keuangan Publik yang Berdimensi Penghormatan terhadap Badan Hukum. Depok: Bidang Studi HAN FH UI, h. 19-20.

23 Pasal 1 angka 2 Undang-Undang Nomor 19 Tahun 2003 tentang Badan Usaha Milik Negara.

24 Pasal 1 angka 4 Undang-Undang Nomor 19 Tahun 2003 tentang Badan Usaha Milik Negara. 
dalam rezim ini akan berpengaruh pula pada mekanisme pemeriksaan keuangan BUMN yang tidak lagi berprinsip pada sistem APBN atau pada norma pemeriksaan keuangan pada instansi pemerintahan, namun pada prinsip-prinsip perusahaan yang sehat serta pertanggungjawaban Direksi BUMN dalam melaksanakan usaha BUMN sesuai dengan ketentuan peraturan perundang-undangan tentang Perseroan Terbatas.

\section{Transformasi Status Hukum Kekayaan Negara yang Dipisahkan dalam Badan Usaha Milik Negara}

Seperti yang telah dijelaskan sebelumnya, peraturan perundang-undangan memberikan definisi BUMN sebagai badan usaha yang seluruh atau sebagian besar modalnya dimiliki oleh negara melalui penyertaan secara langsung yang berasal dari kekayaan negara yang dipisahkan. BUMN sendiri dapat berbentuk perusahaan perseroan yang modalnya terbagi dalam saham yang seluruh atau minimal 51\% sahamnya dimiliki oleh negara yang tujuan utamanya mengejar keuntungan; serta perusahaan umum yang seluruh modalnya dimiliki negara dan tidak terbagi atas saham yang bertujuan untuk kemanfaatan umum.

Atas hal tersebut, Hakim Konstitusi Harjono dalam dissenting opinion Putusan Mahkamah Konstitusi Nomor 62/PUU-XI/2013 menyatakan bahwa terdapat hubungan negara terhadap BUMN dalam bentuk Perseroan yakni suatu hubungan kepemilikan sebagai pemegang saham Perseroan Terbatas yang hak dan kewajibannya tunduk pada UndangUndang Perseroan Terbatas. Sehingga, negara seharusnya tidak lagi mempunyai kekuasaan yang bebas terhadap sebagian kekayaan negara yang dipisahkan untuk menjadi modal perseroan karena telah dikonversi menjadi hak pemegang saham sebagaimana diatur dalam Undang-Undang Perseroan Terbatas.

Selanjutnya, ia menerangkan bahwa dengan dikonversi kekayaan negara menjadi saham dalam presentase yang tercermin sebagai hak suara dalam Rapat Umum Pemegang Saham dan hak untuk mendapatkan deviden, maka hubungan negara dengan kekayaan yang semula dimilikinya menjadi putus. ${ }^{25}$ Hak kepemilikan yang ada pada negara akan digantikan oleh hak pemegang saham, dalam proses tersebut terjadi suatu transformasi status hukum dari keuangan negara, menjadi keuangan badan hukum. Sehingga, pengelolaan, tanggung jawab serta beban risiko berpindah dari negara ke BUMN. Apabila kepemilikan negara masih melekat, justru menjadi suatu paradoks karena negara menjadi memiliki dua titel hak atas satu barang yang sama, yakni hak pemegang saham dan hak kepemilikan.

Menurut Arifin P. Soeria Atmadja, dalam arsitektur keuangan publik, keuangan BUMN memiliki kapasitas hukum sendiri yang berbeda dengan badan hukum lainnya karena BUMN memiliki kapasitas hukum perdata, sehingga tata kelola dan tanggung jawabnya pun berdasarkan ketentuan hukum perdata. Negara, dalam kedudukannya di BUMN, merupakan subyek hukum perdata yang tindakan hukumnya semula dalam bentuk tugas dan kewenangan (taak en bevoegheid) berubah menjadi hak dan kewajiban (bekwaamheid) sebagai akibat dari transaksi horizontal, yakni pemberian modal oleh negara kepada BUMN, yang tunduk pada rezim hukum perdata. ${ }^{26}$ Oleh sebab itu, negara sebagai subyek hukum publik tidak memiliki kewenangan dalam hukum perdata untuk mengintervensi BUMN yang menjadikan BUMN tidak mandiri maupun bersaing dengan sesama badan usaha privat lainnya. Dalam konsep bisnis, sulit dilakukan jika regulasi terhadap BUMN masih memiliki pola pikir serba-negara yang berakibat selain BUMN tidak mampu berkompetisi, juga tidak

25 Putusan Mahkamah Konstitusi Nomor 62/PUU-XI/2013, h. 237-238. 33.

26 Arifin P. Soeria Atmadja. (2014). Aktualisasi Hukum Keuangan Publik. Bandung: Mujahid Press, h. 
mampu untuk menghasilkan portofolio bisnis yang menjadi mesin pertumbuhan ekonomi negara. $^{27}$

\section{Alasan Pembebanan Tanggung Jawab pada Direksi Badan Usaha Milik Negara atas Keputusa Bisnis yang Dibuatnya}

Kepastian mengenai dualisme yang dibahas dalam pokok bahasan sebelumnya menjadi penting ketika dihadapkan dengan pokok pembahasan selanjutnya ini. Sudah terang bahwasannya secara teoritis seharusnya kekayaan BUMN adalah terpisah dari kekayaan negara. Penegasan tersebut menjadi penting karena kegiatan usaha termasuk dalam BUMN adalah kegiatan yang penuh dengan kemungkinan baik dan buruk suatu hasil serta tingginya persaingan. Kemudian, karena adanya kemungkinan-kemungkinan buruk tersebut diperlukan kepastian apakah beban yang dipertanggungkan kepada direksi BUMN adalah juga banyak masuk kedalam lingkungan hukum publik misalkan yang paling dekat adalah korupsi (Dalam hal kekayaan negara dan BUMN disatukan), atau hanya lingkungan hukum privat dan sedikit hukum publik (Dalam hal kekayaan negara dan BUMN dipisahkan).

Di sisi lain, dikarenakan adanya kemungkinan baik dan buruk dari hasil suatu kegiatan usaha, berakibat pada dituntutnya direksi selaku pihak yang memiliki kewenangan dalam menjalankan perseroan untuk dapat mengambil suatu kebijakan secara tepat dan cepat. Dalam setiap kerugian yang timbul dari suatu keputusan direksi, tidak serta merta segalanya dipersalahkan atau dimintakan pertanggungjawaban kepada direksi, perseroan juga dapat menanggung risiko bisnis yang timbul dari pengambilan kebijakan oleh direksi. Hal ini sejalan dengan apa yang dikemukakan oleh Munir Fuady, bahwa seorang direktur tidak serta merta dapat dimintai pertanggungjawaban hanya karena alasan salah dalam memutuskan atau hanya karena alasan kebijakan bisnis yang diambilnya mengakibatkan kerugian. ${ }^{28}$ Jika terjadi kerugian, masih dapat ditoleransi dengan batas-batas tertentu mengingat tidak semua bisnis harus mendapat keuntungan. Hal sedemikan rupa yang kemudian disebut sebagai doktrin business judgment rule. Doktrin tersebut kemudian yang seharusnya digunakan menjadi parameter untuk melindungi ataupun menyalahkan dan kemudian meminta pertanggungjawaban kepada direksi dalam setiap keputusan yang diambil oleh direksi suatu korporasi yang dalam hal ini dalam bentuk BUMN.

Black's Law Dictionary mendefinisikan Business Judgment Rule sebagai "the presumption that in making business decision not involving direct self interest or self dealing, corporate directors act in the honest belief that their actions are in the corporation best interest." 29 Dengan kata lain, Business Judgment Rule sebagai suatu tindakan dalam membuat suatu kebijakan bisnis yang tidak melibatkan kepentingan diri sendiri, kejujuran dan mempertimbangkan yang terbaik bagi perusahaan. Sedangkan, Robert Charles Clark mengartikan Business Judgment Rule, yaitu:...a presumption that in making a business decision, the director of corporation acted on an informed basis in good faith and the honest belief that the action was taken in the best interest of the company. ${ }^{30}$

Kedua penjelasan di atas kembali menegaskan bahwa doktrin Business Judgment Rule sesungguhnya melindungi direksi atas setiap keputusan bisnis yang merupakan transaksi perseroan, selama hal itu dilakukan dalam batas-batas kewenangan dengan penuh kehati-

27 Arifin P. Soeria Atmadja. (2013). Keuangan Publik dalam Perspektif Hukum. Jakarta: Rajawali Press, h. $119-120$.

28 Munir Fuady. (2002). Doktrin-Doktrin Modern dalam Corporate Law dan Esksistensinya dalam Hukum Indonesia. Bandung: Citra Aditya Bakti, h. 199.

29 Bryan A. Garner. (2010). Black's Law Dictionary. Toronto: Thomson Group, h. 212.

30 Robert Charles Clark. (1986). Corporate Law. New York: Aspen Publisher, h.123. 
hatian dan itikad baik. Doktrin Business Judgment Rule muncul diawali dari beberapa kasus yang terjadi di beberapa negara bagian Amerika Serikat, kemudian dari kasus-kasus tersebut menimbulkan kesan bahwa direksi sering ditempatkan sebagai pihak yang selalu dipersalahkan dalam perseroan. Kesan tersebut tidak mencerminkan keadilan, karena direksi bukanlah pihak yang selalu dapat dipersalahkan sepenuhnya atas pengelolaan perusahaan atau dengan kata lain tanggung jawab tidak dapat dibebankan secara penuh kepada direksi. ${ }^{31}$

Doktrin Business Judgment Rule lahir sebagai akibat adanya doktrin fiduciary duty. Secara singkat, Business judgment rule merupakan reaksi atas pembatasan diskresi yang timbul karena adanya kewajiban-kewajiban fiduciary bagi direksi dalam mengurus perseroan. ${ }^{32}$ Boen mengumpamakan bahwa fiduciary duty adalah pohon dari buah yang bernama business judgment rule. ${ }^{33}$ Sehingga, jika pohonya dirawat dengan baik (fiduciary duty dijalankan dengan baik) maka akan menghasilkan buah yang baik (Business Judgement Rule), sedangkan bila pohonnya tidak dirawat dengan baik (fiduciary duty dijalankan dengan tidak baik atau tidak dijalankan) maka akan menghasilkan buah yang buruk atau tidak menghasilkan buah sama sekali.

Pada dasarnya, dalam terminologi hukum pemegang fiduciary duty, menurut Black's Law Dictionary adalah: "A person holding the character of a trustee, or a character analogous to that of trustee, in respect to the trust and confidence involved in it and the scrupulous good faith and candor which it requires." 34 Dengan kata lain, seseorang yang memegang peranan sebagai trustee (wali amanat) atau suatu peranan yang mirip dengan trustee terkait dengan adanya kepercayaan dan keyakinan yang terdapat di dalamnya dan itikad baik secara seksama dan kejujuran. Sebagai organ dari perseroan, direksi memiliki kewajiban menjalankan fiduciary duty terhadap perseroan, bukan terhadap pemegang saham baik secara individu maupun kelompok. ${ }^{35}$ Karena itu, hanya perseroan yang dapat memaksa direksi untuk menjalankan tugas fiduciary duty tersebut. Lebih lanjut, Berdasarkan putusanputusan yang dikeluarkan oleh Delaware Supreme Court di Amerika, direktur mempunyai tugas untuk mencapai manfaat/kepentingan terbaik (best interest) bagi perseroan termasuk pemegang sahamnya. ${ }^{36}$ Tugas Direktur ini menurut Delaware Supreme Court disebut fiduciary duties, yang terdiri dari: care, loyalty dan good faith. ${ }^{37}$

Duty of care sebagai bagian dari fiduciary duties, juga sebagai dasar pemeriksaan apakah direksi memenuhi standar tingkah laku yang patut. Direksi yang bertindak dengan itikad baik diartikan tidak memiliki kepentingan pribadi, dan tugas berikutnya adalah bertindak dengan hati-hati. Esensi yang penting dari duty of care adalah sikap hati-hati atau prudent, dengan ukuran bertindak seperti seorang biasa yang hati-hati dalam mengurus urusannya sendiri. ${ }^{38}$ Kewajiban untuk bertindak dengan hati-hati atau duty of care menuntut direksi untuk membuat kebijakan bisnis, melalui suatu proses pengambilan kebijakan, dengan tingkat kehati-hatian yang umumnya digunakan oleh orang biasa dalam keadaan

31 Robert Prayoko. (2015). Doktrin Business Judgement Rule: Aplikasinya dalam Hukum Perusahaan Modern. Yogyakarta: Graha Ilmu, h. 2.

32 Freddy Harris, Teddy Anggoro. (2010). Hukum Perseroan Terbatas: Kewajiban Pemberitahuan Direksi. Bogor: Ghalia Indonesia, h. 59.

33 Hendra Setiawan Boen. (2008). Bianglala Business Judgement Rule. Jakarta: Tatanusa, h. 102 dan 110.

34 Bryan A. Garner. (2010). Black's Law Dictionary. Toronto: Thomson Group, h. 625.

35 Janet Dine. (2001). Company Law. London: Sweet \& Maxwell, h. 7.

36 Agustina Arumsari. (2014). Analisis Keputusan Bisnis pada Badan Usaha Milik Negara Berbentuk Perseroan Melalui Penerapan Doktrin Fiduciary Duty Dan Business Judgment Rule Direksi (Studi Kasus Tindak Pidana Korupsi Direktur BUMN). Tesis, Universitas Indonesia, h. 26.

37 Ibid.

38 Sean J. Griffith. (2005). Good Faith Business Judgment: A Theory of Rhetoric in Corporate Law Jurisprudence. Duke Law Journal 55 (1): 1-72, h. 10. 
yang sama dengan mempertimbangkan informasi yang tersedia secara wajar. Penggunaan informasi yang cukup dalam pertimbangan untuk membuat suatu kebijakan merupakan usaha itikad baik yang diperlukan dalam melakukan duty of care. ${ }^{39}$

Kriteria care dalam penggunaan business judgment rule dapat dipenuhi dengan pertimbangan, direktur telah memperoleh dan menggunakan materi serta pendapat dari para ahli dan profesional seperti: ${ }^{40}$ apraisal independen, manajer investasi, dan konsultan hukum (walaupun dalam business decision-making, tidak menjadi keharusan mutlak bagi Direktur untuk mengikuti saran dari mereka). Namun sesungguhnya, duty of care, cukup dipenuhi dengan menyewa profesional yang diperlukan untuk mengumpulkan semua informasi terkait yang dibutuhkan, kemudian memberikan perhatian yang patut kepada bisnis perseroan yang akan dijalankan. ${ }^{41}$

Duty of loyalty memerintahkan bahwa best interest bagi perseroan dan pemegang sahamnya harus didahulukan atau 'mengambil tempat utama' di atas semua kepentingan yang dimiliki oleh direktur, manajer, pegawai bahkan diatas kepentingan yang dimiliki oleh pemegang saham pengendali (controlling shareholder) sekalipun. ${ }^{42}$ Pada awalnya dalam pelaksanaan duty of loyalty, direksi tidak boleh sama sekali terlibat dalam transaksi conflict of interest, artinya direksi tidak boleh mencari keuntungan pribadi dan biaya-biaya yang telah dikeluarkan oleh perseroan. ${ }^{43}$ Namun dalam perkembangannya, duty of loyalty menjadi konsep yang berbeda, yakni mengakui adanya harga yang wajar (fair price), dan ada kesepakatan yang wajar (fair dealing). ${ }^{44}$ Standar ini menghendaki agar direktur 'yang mempunyai kepentingan' (interested director) dan atau 'yang mempunyai kekuasaan dominan dan kendali' terhadap direktur lainnya (dominating director), mempunyai beban untuk membuktikan the entire fairness pada transaksi yang dilakukan oleh perseroan sebelum pengadilan menetapkan asumsi business judgment rule terhadapnya. ${ }^{45}$

Sedangkan, Duty of good faith menghendaki agar Direktur bertindak dengan 'kejujuran dalam mencapai tujuan' (honesty of purpose). ${ }^{46}$ 'Itikad baik' (good faith) merupakan segala sesuatu yang terdapat dalam keadaan pikiran Direktur (is all about the director's state of mind), contohnya, Direktur percaya dan yakin, tindakannya tersebut dalam rangka mencapai kepentingan terbaik bagi perseroan. ${ }^{47}$

Selain itu, doktrin Business Judgment Rule memberikan dorongan kepada direksi agar berani mengambil kebijakan serta risiko dalam melaksanakan tugas dan kewajibannya mengurus perseroan. Direksi tidak diperkenankan takut terhadap ancaman yang mengakibatkan direksi bertanggung jawab secara pribadi atas kerugian perseroan, yang mungkin timbul akibat dari tindakan maupun kebijakan bisnis yang diambilnya, dalam

39 Nadelle Grossman. (2007). Director Compliance with Elusive Fiduciary Duty in a Climate of Corporate Governance Reform. Fordham Journal of Corporate \& Financial Law 12, h. 402.

40 William M. Roberts. (1991). Searching For A Paradigm For The Fiduciary Duties Of Corporate Directors. Memphis State University Law Review, h. 504.

41 Ibid.

42 Thomas A. Uebler. (2008). Shareholder Police Power: Shareholders' Ability To Hold Directors Accountable For Intentional Violations Of Law. Delaware Journal Of Corporate Law, h. 203.

43 William M. Roberts. (1991). Searching For A Paradigm For The Fiduciary Duties Of Corporate Directors. Memphis State University Law Review, h. 505.

44 W. Knepper, D. Bailey. (1988). Liability of Corporate Officers and Directors. h. 82.

45 William M. Roberts. (1991). Searching For A Paradigm For The Fiduciary Duties Of Corporate Directors. Memphis State University Law Review, h. 505.

46 Andrew S. Gold. (2007). A Decision Theory Approach To The Business Judgment Rule: Reflections On Disney, Good Faith, And Judicial Uncertainty. Maryland Law Review, h. 406

47 Ibid. 
Hukum Indonesia, doktrin fiduciary duty dan business judgment rule secara implisit telah diatur dalam Pasal 92 dan Pasal 97 UU PT yang mengatur sebagai berikut:

Pasal 92:

(1) Direksi menjalankan pengurusan perseroan untuk kepentingan perseroan dan sesuai dengan maksud dan tujuan perseroan.

(2) Direksi berwenang menjalankan pengurusan sebagaimana dimaksud pada ayat (1) sesuai dengan kebijakan yang dipandang tepat, dalam batas yang ditentukan dalam undang-undang ini dan/atau anggaran dasar.

Pasal 97:

(1) Direksi bertanggung jawab atas pengurusan perseroan sebagaimana dimaksud dalam pasal 92 ayat (1).

(2) Pengurusan sebagaimana dimaksud pada ayat (1) wajib dilaksanakan setiap anggota direksi dengan itikad baik dan penuh tanggung jawab.

(3) Setiap anggota direksi bertanggung jawab penuh secara pribadi atas kerugian perseroan apabila yang bersangkutan bersalah atau lalai menjalankan tugasnya sesuai dengan ketentuan sebagaimana dimaksud pada ayat (2).

(4) Dalam hal Direksi terdiri atas 2 (dua) anggota Direksi atau lebih, tanggung jawab sebagaimana dimaksud pada ayat (3) berlaku secara tanggung renteng bagi setiap anggota Direksi.

(5) Anggota Direksi tidak dapat dipertanggungjawabkan atas kerugian sebagaimana dimaksud pada ayat (3) apabila dapat membuktikan:

a. kerugian tersebut bukan karena kesalahan atau kelalaiannya;

b. telah melakukan pengurusan dengan itikad baik dan kehati-hatian untuk kepentingan dan sesuai dengan maksud dan tujuan Perseroan;

c. tidak mempunyai benturan kepentingan baik langsung maupun tidak langsung atas tindakan pengurusan yang mengakibatkan kerugian; dan

d. telah mengambil tindakan untuk mencegah timbul atau berlanjutnya kerugian tersebut.

Pengaturan UU PT tersebut menetapkan kualifikasi-kualifikasi yang dapat membebaskan direksi dari pertanggungjawaban pribadi, ketentuan pasal 97 ayat (5) menggambarkan dengan jelas keberlakuan doktrin business judgment rule dalam konsep standard judicial review. Karena, dalam peraturan UU PT tersebut terdapat anak kalimat “...apabila dapat membuktikan...”. Kalimat tersebut menunjukan bahwa penerapan doktrin business judgment rule di Indonesia harus dibuktikan di pengadilan. Hal ini sangat berbeda dengan konsep business judgment rule in abstention doctrine, jika nyata-nyata direksi dalam mengambil keputusannya telah memenuhi kriteria business judgment rule, maka dia tidak dapat dihadapkan ke pengadilan. ${ }^{48}$

Dengan kata lain, kata-kata.”...apabila dapat membuktikan...” menunjukkan bahwa anggota direksilah yang harus membuktikan bahwa dirinya telah memenuhi unsur huruf a.b.c.dan d tersebut diatas. Pembelaan diri dalam Pasal 97 ayat (5) UU PT sebagaimana tersebut diatas bersifat kumulatif, sehingga semua unsur harus dibuktikan oleh Direktur BUMN Persero agar ia terbebas dari pembebanan tanggung jawab pribadi ataupun tanggung jawab secara tanggung renteng, sebaliknya pemegang saham atas nama persero tidak dapat menambah unsur baru selain yang diatur dalam Pasal 97 ayat (5) UU PT tersebut agar

48 Freddy Harris, Teddy Anggoro. (2010). Hukum Perseroan Terbatas: Kewajiban Pemberitahuan Direksi. Bogor: Ghalia Indonesia, h. 62. 
direktur dapat dibebani tanggung jawab pribadi ataupun tanggung jawab secara tanggung renteng. ${ }^{49}$

Terkait dengan unsur Pasal 97 ayat (5) huruf b yaitu telah melakukan pengurusan dengan itikad baik dan kehati-hatian untuk kepentingan dan sesuai dengan maksud dan tujuan perseroan harus dipenuhi ke semua unsur tersebut. Itikad baik berkaitan dengan hati seseorang. Sedangkan kehati-hatian telah dijelaskan sebelumnya ketika membahas mengenai salah satu unsur fiduciary duty yaitu duty of care. Joseph T. Wells mengungkapkan teori "prudent man", yang menyatakan bahwa adanya korelasi tingkat kehati-hatian dengan lingkungan dan kebiasaan dalam suatu bisnis. Inti dari teori "prudent man" adalah kebiasaan atau kelaziman yang masuk akal yang dilakukan karyawan atau direksi dalam situasi yang sama atau serupa. ${ }^{50}$ Untuk menegaskan hal tersebut Pasal 5 ayat (3) UU BUMN mengatur: Dalam melaksanakan tugasnya, anggota direksi harus mematuhi anggaran dasar BUMN dan peraturan perundang-undangan serta wajib melaksanakan prinsip-prinsip profesionalisme, efisiensi, transparansi, kemandirian, akuntabilitas, pertanggungjawaban, serta kewajaran.

Kemudian, unsur tidak mempunyai benturan kepentingan baik langsung maupun tidak langsung atas tindakan pengurusan yang mengakibatkan kerugian. Direksi harus menghindari benturan kepentingan atau conflict of interest untuk menjamin keputusan yang diambil dari pengurusan perusahaan semata-mata untuk kepentingan perusahaan. Sebagai pencegahannya, UU PT telah melarang direksi yang terdapat benturan kepentingan dengan perseroan untuk mewakili perusahaan dalam proses pengambilan keputusan. ${ }^{51}$ Untuk menghindari terjadi transaksi yang dapat mendorong terjadinya benturan kepentingan maka, menurut Bismar Nasution, paling tidak ada tiga jenis transaksi yang harus dihindari oleh para direksi dalam mengambil keputusan bisnis, yaitu seorang direksi melakukan transaksi dengan perusahaannya sendiri; dua perusahaan yang mempunyai satu orang direksi yang sama melakukan perjanjian; dan sebuah induk perusahaan melakukan transaksi direksi dengan cabang perusahaannya sendiri. ${ }^{52}$

Pasal 7 UU BUMN mengatur bahwa para anggota direksi, komisaris dan dewan pengawas dilarang mengambil keuntungan pribadi baik secara langsung maupun tidak langsung dari kegiatan BUMN selain penghasilan yang sah. Selanjutnya, unsur telah mengambil tindakan untuk mencegah timbul atau berlanjutnya kerugian tersebut. Penjelasan mengenai hal ini pada UU PT menyebutkan bahwa yang dimaksud dengan mengambil tindakan untuk mencegah timbul atau berlanjutnya kerugian termasuk juga langkah-langkah untuk memperoleh informasi mengenai tindakan pengurusan yang dapat mengakibatkan kerugian antara lain melalui forum rapat direksi. Upaya pencegahan terjadinya pengurusan perusahaan yang tidak baik juga dapat ditemui dalam penerapan prinsip-prinsip Good Corporate Governance. Terkait BUMN secara khusus Good Corporate Governance diatur dalam Peraturan Menteri Negara BUMN Nomor PER-01/MBU/2011 tentang Penerapan Tata Kelola Perusahaan Yang Baik (Good Corporate Governance) Pada Badan Usaha Milik Negara sebagai berikut: ${ }^{53}$

49 Agustina Arumsari. (2014). Analisis Keputusan Bisnis pada Badan Usaha Milik Negara Berbentuk Perseroan Melalui Penerapan Doktrin Fiduciary Duty Dan Business Judgment Rule Direksi (Studi Kasus Tindak Pidana Korupsi Direktur BUMN). Tesis, Universitas Indonesia, h. 44.

50 Joseph T. Wells. (1992). Fraud Examination: Investigative and audit Procedures. Connecticut: Quarum Books, h. 97.

51 Pasal 99 ayat (1) Undang-Undang Nomor 40 Tahun 2007 tentang Perseroan Terbatas.

52 Agustina Arumsari. (2014). Analisis Keputusan Bisnis pada Badan Usaha Milik Negara Berbentuk Perseroan Melalui Penerapan Doktrin Fiduciary Duty Dan Business Judgment Rule Direksi (Studi Kasus Tindak Pidana Korupsi Direktur BUMN). Tesis, Universitas Indonesia, h. 46.

53 Pasal 19 Peraturan Menteri BUMN Nomor PER-01/MBU/2011 tentang Penerapan Tata Kelola 
(1) Direksi harus melaksanakan tugasnya dengan itikad baik untuk kepentingan BUMN dan sesuai dengan maksud dan tujuan BUMN, serta memastikan agar BUMN melaksanakan tanggung jawab sosialnya serta memperhatikan kepentingan dari berbagai pemangku kepentingan sesuai dengan ketentuan peraturan perundangundangan

(2) Salah seorang anggota Direksi ditunjuk oleh Rapat Direksi sebagai penanggung jawab dalam penerapan dan pemantauan GCG di BUMN yang bersangkutan.

(3) Direksi harus menyampaikan informasi mengenai identitas, pekerjaan-pekerjaan utamanya, jabatan Dewan Komisaris di anak perusahaan/perusahaan patungan dan/atau perusahaan lain, termasuk rapat-rapat yang dilakukan dalam satu tahun buku (rapat internal maupun rapat gabungan dengan Dewan Komisaris/Dewan Pengawas), serta gaji, fasilitas, dan/atau tunjangan lain yang diterima dari BUMN yang bersangkutan dan anak perusahaan/perusahaan patungan BUMN yang bersangkutan, untuk dimuat dalam Laporan Tahunan BUMN.

(4) Direksi wajib melaporkan kepada BUMN mengenai kepemilikan sahamnya dan/atau keluarganya (istri/suami dan anak-anaknya) pada BUMN yang bersangkutan dan perusahaan lain, termasuk setiap perubahannya.

Dapat disimpulkan, karena Pasal 11 UU BUMN menegaskan bahwa terhadap BUMN Persero berlaku segala ketentuan dan prinsip-prinsip yang berlaku bagi perseroan terbatas, oleh karena itu doktrin fiduciary duty dan business judgment rule yang telah diserap dalam UU PT juga berlaku di BUMN yang berbentuk perseroan. Doktrin tersebut kemudian yang seharusnya digunakan menjadi parameter untuk melindungi ataupun menyalahkan dan kemudian meminta pertanggungjawaban kepada direksi dalam setiap keputusan yang diambil oleh direksi suatu korporasi yang dalam hal ini BUMN.

\section{P E N U T U P}

Peraturan perundang-undangan Indonesia memiliki inkonsistensi dalam memaknai konsep kekayaan negara yang dipisahkan dalam BUMN. Pada pandangan pertama, penyertaan modal negara ke BUMN akan tetap menjadi kekayaan negara, bukan menjadi modal BUMN sepenuhnya. Sehingga, norma pemeriksaan pada BUMN dilakukan berdasarkan sistem APBN dan norma pemeriksaan keuangan instansi pemerintahan. Sedangkan, pandangan kedua berpedoman bahwa kekayaan negara yang dipisahkan setelah diberikan ke BUMN tidak akan lagi menjadi kekayaan negara. Sehingga, norma pemeriksaan keuangan BUMN menggunakan prinsip-prinsip perusahaan yang sehat.

Dalam teori transformasi status hukum keuangan negara, hubungan negara terhadap BUMN dalam bentuk Perseroan yakni suatu hubungan kepemilikan sebagai pemegang saham Perseroan Terbatas yang hak dan kewajibannya tunduk pada Undang-Undang Perseroan Terbatas. Sehingga, hak kepemilikan yang ada pada negara akan digantikan oleh hak pemegang saham dan pengelolaan, tanggung jawab serta beban risiko berpindah dari negara ke BUMN begitu terjadi transaksi horizontal berupa pemisahan kekayaan negara yang dipisahkan ke BUMN. Keuangan BUMN juga memiliki kapasitas hukum perdata, sehingga tata kelola dan tanggung jawabnya pun berdasarkan ketentuan hukum perdata. Oleh sebab itu, negara sebagai subyek hukum publik tidak memiliki kewenangan dalam hukum perdata untuk mengintervensi BUMN, hanya dapat dilakukan dalam konteks negara sebagai badan hukum perdata atau pemegang saham dari BUMN.

Perusahaan Yang Baik (Good Corporate Governance) Pada Badan Usaha Milik Negara 
Adanya kemungkinan baik dan buruk dari hasil suatu kegiatan usaha, berakibat pada dituntutnya direksi selaku pihak yang memiliki kewenangan dalam menjalankan perseroan untuk dapat mengambil suatu kebijakan secara tepat dan cepat. Dalam setiap kerugian yang timbul dari suatu keputusan direksi, tidak serta merta segalanya dipersalahkan atau dimintakan pertanggungjawaban kepada direksi, perseroan juga dapat menanggung risiko bisnis yang timbul dari pengambilan kebijakan oleh direksi. Jika terjadi kerugian, masih dapat ditoleransi dengan batas-batas tertentu mengingat tidak semua bisnis harus mendapat keuntungan. Hal itu yang disebut sebagai doktrin business judgment rule. Doktrin tersebutlah kemudian yang seharusnya digunakan menjadi parameter dan alasan untuk melindungi ataupun menyalahkan dan kemudian meminta pertanggungjawaban kepada direksi dalam setiap keputusan yang diambil oleh direksi suatu korporasi yang dalam hal ini dalam bentuk Badan Usaha Milik Negara.

Untuk mewujudkan optimalisasi BUMN sebagai salah satu pelaku perekonomian nasional yang bertujuan untuk mencapai kesejahteraan umum, perlu dilakukan penyeragaman peraturan perundang-undangan Indonesia mengenai konsep kekayaan negara yang dipisahkan pada BUMN dengan berpatokan pada teori transformasi status hukum kekayaan negara yang dipisahkan menjadi keuangan BUMN dan menegaskan bahwa BUMN merupakan sepenuhnya subjek hukum privat yang tidak dapat dilakukan pemeriksaan berdasarkan norma pemeriksaan yang ada pada instansi pemerintahan, atau negara sebagai badan hukum publik. Karena BUMN berbentuk perseroan telah ditegaskan merupakan sepenuhnya subjek hukum privat maka doktrin yang seharusnya digunakan untuk menjadi dasar atau alasan perlindungan ataupun penjatuhan pertanggungjawaban bagi direksi BUMN adalah doktrin business judgment rule

\section{DAFTAR PUSTAKA}

\section{Jurnal}

[1] Ais, Chatamarrajid. (2001). "Fiduciary Duty" sebagai Standar Para Direksi dalam Melaksanakan Tugasnya. Hukum dan Pembangunan 1 (XXXI): 63-72.

[2] Arsht, S. Samuel. (1979). The Business Judgment Rule Revisited". Hofstra Law Review 8.

[3] Brennan, Bartley A. (1991). Current Developments Surrounding The Business Judgment Rule: A 'Race To The Bottom' Theory Of Corporate Law Revived. Whittier Law Review: 301.

[4] Gold, Andrew S. (2007). A Decision Theory Approach To The Business Judgment Rule: Reflections On Disney, Good Faith, And Judicial Uncertainty. Maryland Law Review.

[5] Griffith, Sean J. (2005). Good Faith Business Judgment: A Theory of Rhetoric in Corporate Law Jurisprudence. Duke Law Journal, 55.

[6] Grossman, Nadelle. (2007) Director Compliance with Elusive Fiduciary Duty in a Climate of Corporate Governance Reform.Fordham Journal of Corporate \& Financial Law, 12.

[7] Juliani, Henny. (2018). Aspek Yuridis Transformasi Hukum Keuangan Publik ke Keuangan Privat terhadap Pengelolaan Kekayaan Negara yang Dipisahkan pada BUMN. Administrative Law \& Governance Journal, 4 (2).

[8] Juliani, Henny. (2016). Pertanggungjawaban Direksi BUMN terhadap Perbuatan yang Mengakibatkan Kerugian Keuangan Negara. Masalah-Masalah Hukum 45 (4): 299306. 
[9] Khairandy, Ridwan. (2007). Konsepsi Kekayaan Negara Yang Dipisahkan Dalam Perusahaan Perseroan. Jurnal Hukum Bisnis 26 (1).

[10]Lestari, Sartika Nanda. (2015). Business Judgement Rule sebagai Immunity Doctrine bagi Direksi Badan Usaha Milik Negara di Indonesia. Notarius 8 (2): 302-315.

[11] McMillan, Lori. (2013). The Business Judgment Rule As An Immunity Doctrine. William \& Mary Business Law Review 4.

[12] Paputungan, Merdiansa. (2017). Diskursus Kewenangan Audit BPK terhadap Keuangan BUMN (Perseroan) Pasca Putusan MK Nomor 62/PUU-XI/2013. Mimbar Hukum 29 (3): 430-444.

[13] Pramono, Nindyo. (2007). Tanggung Jawab dan Kewajiban Pengurus PT (Bank) Menurut UU No.40 Tahun 2007 tentang Perseroan Terbatas. Buletin Hukum Perbankan dan Kebanksentralan 5 (3).

[14]Roberts, William M. (1991). Searching For A Paradigm For The Fiduciary Duties Of Corporate Directors. Memphis State University Law Review.

[15] Sjahdeini, Sutan Remy. (2001). Tanggung Jawab Pribadi Direksi dan Komisaris. Jurnal Hukum Bisnis 14.

[16] Triem, Fred W. (2007). Judicial Schizophrenia in Corporate Law: Confusing The Standard of Care With The Business Judgment Rule. Alaska Law Review.

[17]Uebler, Thomas A. (2008). Shareholder Police Power: Shareholders' Ability To Hold Directors Accountable For Intentional Violations Of Law. Delaware Journal of Corporate Law.

[18] Wuisang, Ari. (2015). Transformasi Keuangan Publik menjadi Keuangan Perdata dalam Pendirian Badan Usaha Milik Negara (BUMN) oleh Pemerintah. Pakuan Law Review 1 (2).

\section{Buku}

[19] Atmadja, Arifin P. Soeria. (2014). Aktualisasi Hukum Keuangan Publik. Bandung: Mujahid Press.

[20] Atmadja, Arifin P. Soeria. (2013). Keuangan Publik dalam Perspektif Hukum. Jakarta: Rajawali Press.

[21] Atmadja, Arifin P. Soeria. (2007). Transformasi Status Hukum Uang Negara sebagai Teori Keuangan Publik yang Berdimensi Penghormatan terhadap Badan Hukum. Depok: Bidang Studi HAN FH UI.

[22] Boen, Hendra Setiawan. (2008). Bianglala Business Judgment Rule. Jakarta: PT Tatanusa.

[23] Clark, Robert Charles. (1986). Corporate Law. New York: Aspen Publisher.

[24]Dine, Janet. (2001). Company Law. London: Sweet \& Maxwell.

[25]Fuady, Munir. (2002). Doktrin-doktrin Modern Dalam Corporate Law dan Eksistensinya dalam Hukum Indonesia. Bandung: Citra Aditya Bakti.

[26] Garner, Bryan A. (2010). Black's Law Dictionary. Toronto: Thomson Group.

[27]Harris, F., Anggoro, T. (2010). Hukum Perseroan Terbatas: Kewajiban Pemberitahuan Direksi. Bogor: Penerbit Ghalia Indonesia.

[28] Knepper, W., Bailey, D. (1988). Liability of Corporate Officers and Directors. New York: LexisNexis.

[29]Prayoko, Robert. (2015). Doktrin Business Judgment Rule; Aplikasinya dalam Hukum Perusahaan Modern. Yogyakarta: Graha Ilmu.

[30] Sardjono, A., Dewi, Y. K., Irawaty, R., Pangaribuan, T. (2018). Pengantar Hukum Dagang. Depok: Rajagrafindo Persada.

[31] Soekanto, S., Mamudji, S. (2018). Penelitian Hukum Normatif: Suatu Tinjauan Singkat. Depok: RajaGrafindo Persada 


\section{Skripsi, Tesis, Disertasi dan Lain-Lain}

[32] Arumsari, Agustina. (2014). Analisis Keputusan Bisnis Pada Badan Usaha Milik Negara Berbentuk Perseroan Melalui Penerapan Doktrin Fiduciary Duty Dan Business Judgment Rule Direksi (Studi Kasus Tindak Pidana Korupsi Direktur BUMN). Tesis, Universitas Indonesia.

[33] Atmadja, Arifin P. Soeria. (2004). Carut Marut Undang-Undang Nomor 17 Tahun 2003 tentang Keuangan Negara. Makalah Lepas.

[34] Hambali, Nurul Fauziah. (2018). Penerapan Doktrin Business Judgment Rule Terkait Pertanggungjawaban Pidana Direksi BUMN Dalam Tindak Pidana Korupsi. Tesis, Universitas Indonesia.

[35] Indradewa, Jusuf. (2002). Aspek Hukum dan Hakikat Keuangan Negara dalam Kaitannya dengan Pengelolaan Badan Usaha Milik Negara. Makalah yang disampaikan pada Seminar Reposisi Keuangan Negara: Pengelolaan, Pertanggungjawaban, dan Pemeriksaan Badan Usaha Milik Negara di Jakarta. 